\title{
The Limitations and Exceptions to Immunity of States Officials from Foreign Criminal Jurisdiction: On ILC Draft Article 7
}

\author{
Hu Ren*, Zhaoxin Jin \\ School of Law, East China University of Science and Technology, Shanghai, China \\ Email: *yimhao@hotmail.com
}

How to cite this paper: Ren, H., \& Jin, Z. $X$. (2021). The Limitations and Exceptions to Immunity of States Officials from Foreign Criminal Jurisdiction: On ILC Draft Article 7. Beijing Law Review, 12, 287-304. https://doi.org/10.4236/blr.2021.122017

Received: March 8, 2021

Accepted: April 6, 2021

Published: April 9, 2021

Copyright ( 2021 by author(s) and Scientific Research Publishing Inc. This work is licensed under the Creative Commons Attribution International License (CC BY 4.0).

http://creativecommons.org/licenses/by/4.0/

\section{(c) (i) Open Access}

\begin{abstract}
The International Law Commission (ILC) temporarily adopted Draft Article 7 on immunity of state officials from foreign criminal jurisdiction, listing six international crimes such as genocide and crimes against humanity that state officials don't share immunity from foreign criminal jurisdiction. This paper holds a conservative attitude to the adoption of Draft Article 7 after combing international and national practice and research on immunity theory. First, by sorting out international practices and national practices, it could be drawn that the exception to immunity of state officials from foreign criminal jurisdiction has not yet formed customary international law. Second, through the analysis of the theory and practices, it could be found that the theory for supporting international crimes as exceptions to the immunity of state officials from foreign criminal jurisdiction: international crimes should not be recognized as official acts, the effectiveness of jus cogens is higher than the immunity rule and the theory of impunity against international crimes are not sufficient. Based on the above results, this paper argues that the ILC should not make clarifying immunity exceptions the core of its work on this topic; instead, it should focus on further clarifying the rules for granting state officials immunity from foreign criminal jurisdiction to respect the principle of sovereign equality of states and maintain the stability of international relations.
\end{abstract}

\section{Keywords}

State Officials, Foreign Criminal Jurisdiction, Exceptions to Immunity, International Crimes

\section{Introduction}

The ILC is responsible for developing and codifying the international law with 
the aim of drafting conventions on topics for which international regulations have not yet been established or national practices have not yet fully developed into laws ${ }^{1}$. Since the trials of the Nuremberg Military Tribunal and the International Military Tribunal for the Far East, the immunity of state officials from criminal jurisdiction before international tribunals and foreign domestic courts has been an important issue in international criminal law (Zhu, 2019). Among them, the ILC mainly focused on immunity of state officials from foreign criminal jurisdiction, the fifty-eighth session of ILC in 2006 included this topic in the long-term work schedule ${ }^{2}$, then the fifty-ninth session of ILC officially listed this project in the current working plan ${ }^{3}$. As of March 2021, this topic has lasted for more than a decade, the former Special Rapporteur and the current Special Rapporteur have submitted a total of ten reports on this issue. During this period, the ILC conducted intense discussions on the origins, scope, exceptions and procedures of this issue, resulting in $16 \mathrm{draft}$ articles on immunity of state officials from foreign criminal jurisdiction, of which the first 7 articles were provisionally adopted.

The limitations and exceptions to immunity are a major concern of the international legal community. There are opinions that there should be exceptions to the rules of immunity of state officials, at least the immunity ratione materiae that state officials shall not enjoy immunity when they commit crimes that seriously violate international law (Huang, 2014). In the process of reviewing the preliminary report submitted by the former rapporteur, some members suggested that special attention should be paid to the key issue of whether national officials enjoy immunity when they commit international crimes in follow-up reports ${ }^{4}$. In the preliminary report, the current rapporteur has included the topic that absolute or limited immunity: exceptions and international crimes in the scope of work plan, which would be systematically reviewed in near nature ${ }^{5}$.

The reports submitted by the two rapporteurs reveals that they hold opposite positions on the issue of exceptions to the immunity of state officials of foreign criminal jurisdiction. The former Special Rapporteur pointed out in the second report that the reasons for the exception to immunity were insufficient, and there was not enough practice to prove that the immunity exception has developed into a norm of customary international law $^{6}$. And before clarifying that international crimes have become customary international law, research and discussion on exceptions to immunity should be put on hold (Alebeek, 2018). However, topics that the ILC might include should reflect the needs of member states in the gradual development and codification of international law, they should be 
mature enough in state practice so that they are able to be developed and codified $^{7}$. In this regard, some members believed that the inconsistency of practice cannot be interpreted as the absence of exceptions, yet it was the lack of consistency that made the ILC choose to take exceptions into account. To opposite, the current rapporteur, in her fifth report, believed the conditions for discussing the issue of exceptions have been ripe, the exceptions to immunity have developed into customary international law, and the theoretical basis for immunity exceptions has been sufficient ${ }^{8}$.

The core work of the ILC is to confirm the substantive and procedural rules for granting immunity of state officials from foreign criminal jurisdiction or to research the limitations and exceptions to immunity (Deng, 2016)? The fifth report submitted by the current Special Rapporteur on the issue of immunity exceptions has caused great controversy among representatives, some of whom suggested that the ILC should take a serious attitude since the immunity exceptions of state officials may fundamentally negate the legality of the immunity rule itself. Countries viewed the issue of immunity exceptions from two aspects: one is the impact of immunity exceptions on the purpose of immunity, and the other is the relationship between immunity exceptions and the fight against impunity for the most serious international crimes. ${ }^{9}$. In reality, France issued arrest warrants against a group of senior Rwandan officials in 2006, which triggered strong protests from Rwanda and the African Union. On November 24, 2006, Rwanda announced the severance of diplomatic relations with France due to the "Arrest Warrant" incident and threatened to sue against French citizens in response. The severance of diplomatic relations between the two countries lasted for three years until November 2009. It can be seen that the application of the exception rule of immunity of state officials from foreign criminal jurisdiction by the domestic court of a country will bring great diplomatic pressure to a country, and may affect normal international relations (Wang, 2010).

Regarding the highly controversial issue of immunity exceptions, the current rapporteur believes that the review of immunity exceptions is an indispensable part of the topic, and it is time to review this topic on the basis of sorting out practices. The Draft Article 7, crimes in respect of which immunity does not apply was adopted by the ILC with majority approval on July 20, 2017. It should be noted that the premise for the adoption of this article is that it is not a codification of customary law, but to some extent represents the progressive provisions of international law. In other words, the current article 7 is an essential law rather than an actual law, and it is completely the creation of new law by the ILC (Shi, 2020). It should also be noted that Draft Article 7, as it was provisionally adopted, is different from the Special Rapporteur's proposal, which only addressed immunity ratione materiae and referred only to crimes under international law (Rosca, 2019). The second part of this article will interpret the content 
of Draft Article 7 and analyze the reasons for the proposal of the current Special Rapporteur, the third and the fourth parts will focus on whether the conditions are mature for the review of the exceptions to immunity of state officials from foreign criminal jurisdiction and whether the theory of the exceptions to immunity is sufficient.

\section{The Provisions of Draft Article 7 and the Reasons for Its Adoption}

\subsection{A Brief Description of the Provisions of Draft Article 7}

In view of the pertinence of official immunity, it is necessary to define a set of basic concepts to analyze the issue of exceptions to immunity. Restriction is to delimit the immunity system limit, which is within the immunity system; while exception is to make the immunity system unapplicable, which is outside the immunity system ${ }^{10}$. The distinction between limitation and exception is not clear, limitations and exceptions to immunity is generally used whether in special rapporteur's reports, ILC reports or academic papers ${ }^{11}$. Due to the difficulty of distinctions between limitation and exception, the first part of the Draft Article 7 refers to the techniques used in the issue of immunity from state jurisdiction, using the words "immunity does not apply".

The immunity exception is different from the non-immunity, the immunity exception refers to the situation where officials should enjoy immunity according to the immunity rule, but do not enjoy immunity due to some special reasons such as committing international crimes. For officials who do not enjoy immunity ratione personae, they do not enjoy immunity from foreign criminal jurisdiction in crimes committed in their private capacity, which is non-immunity rather than immunity exception. The Special Rapporteur, the vast majority of state representatives and committee members all hold the same view as the International Court of Justice (ICJ), that the limitations and exceptions to immunity are only applicable to immunity ratione materiae, while the immunity ratione personae is absolute, even when they commit international crimes, they still enjoy absolute immunity ${ }^{12}$. The ILC held the same attitude towards immunity limitations and exceptions and placed Draft Article 7 under the Part three immunity ratione materiae.

Specific to Draft Article 7, it lists crimes of which immunity from foreign criminal jurisdiction shall not apply. The first paragraph lists six crimes including genocide, crimes against humanity, war crimes, apartheid, torture and enforced disappearance. Foreign officials who are accused of committing the above six types of international crimes shall not enjoy immunity even if they are committed in an official capacity. The crimes under international law have nothing to do with whether they are defined as crimes by domestic law. Regarding the

${ }^{10}$ Fifth report, A/CN.4/701, para. 170.

${ }^{11}$ Fourth report on the immunity of State officials from foreign criminal jurisdiction, A/CN.4/686, paras. 122-126.

${ }^{12}$ Sixth report on immunity of State officials from foreign criminal jurisdiction, A/CN.4/722, para. 14. 
first three crimes, the ILC believes that these are crimes of particular concern to the international community and has been adopted in core international criminal treaties and international human rights treaties. Regarding the latter three crimes, the ILC believes that apartheid, torture, and enforced disappearance have always been the subject of international treaties. Although they have been included under Article 7 of the Rome Statute as crimes against humanity, they should still be classified as separate crimes under the consideration of threshold requirements and court practice considerations.

The second paragraph of Draft Article 7 is intended to identify the definition of the crimes listed in paragraph 1 with the aim of retaining the principle of legal certainty in criminal law, providing tools for the interpretation of terms so as to avoid subjective judgments when interpreting these crimes' meaning. The ILC believed that its work did not include the definition of various crimes, so it simply confirmed existing international treaties and included the list contained in the annex. It should be noted that the connection between each crime and the treaties listed in the annex is only for identifying the definition, and there is no need to assume that the country must be a party to the listed treaties. In addition, the list has no effect on the customary nature of these international crimes, and in no way affects customary international law or international treaties that refers to these six international crimes $^{13}$.

\subsection{Reasons for the Adoption of Draft Article 7 by the ILC}

In the process of reviewing the issue of the exceptions to immunity, despite having noticed the judicial practice reasoning process each are not identical, the ILC still insisted that there is a trend in the judicial rulings of national courts to restrict certain acts which are international crimes and shall not apply immunity to these acts based on the firm arguments of the Special Rapporteur ${ }^{14}$. Accordingly, most members of the ILC were of the view that limitations and exceptions to the immunity of State officials from foreign criminal jurisdiction constituted customary international law. Therefore, ILC decided to fulfil its duty which is to promote the progressive development and codification of international law through the application of deductive and inductive methods, so it culminated the listing of crimes under international law not subject to immunity ratione materiae and adopted the Draft Article $7^{15}$.

To be more specific, the Special Rapporteur made her argument from four perspectives to persuade the ILC to adopt Draft Article 7: treaty practice, international judicial practice, national legislative practice and national judicial practice. With regard to international treaties, the Special Rapporteur considers that treaties that directly or indirectly regulate immunity are not sufficient to support

${ }^{13}$ ILC Report, A/72/10, p. 183.

${ }^{14}$ See Regina v. Bow Street Metropolitan Stipendiary Magistrate, (No. 3), House of Lords, United Kingdom, 24 March 1999, [2000] 1 A.C. 147; Re Pinochet, Belgium, Court of First Instance of Brussels, Judgment of 6 November 1998, International Law Reports, Vol. 119, p. 349.

${ }^{15}$ ILC Report, A/72/10, p. 176. 
her views. These treaties do not contain any clauses providing exceptions to immunity, but instead admit that persons with absolute immunity are not subject to jurisdiction. Therefore, she mainly enumerates treaties in the areas of international human rights law and international criminal law, and uses the Convention on the Prevention and Punishment of the Crime of Genocide, the International Convention on the Suppression and Punishment of the Crime of Apartheid as evidence of treaty practice. By focusing on personal criminal responsibility, it is concluded that even if an individual acts in an official capacity, he may also be to bear criminal responsibility since the individual refers to any person, including both state officials and non-state officials. Then the conclusion can be further deduced that genocide, apartheid initially constituted exceptions to criminal jurisdiction immunity.

In terms of international judicial practice, the ICJ and the European Court of Human Rights (ECHR) have discussed limitations and exceptions to immunity of state officials from foreign criminal jurisdiction in a number of judgments. The Special Rapporteur pointed out that although the ICJ did not confirmed exceptions to immunity, it emphasized individual criminal responsibility under international law and believed that individual criminal responsibility is not affected by immunity from criminal jurisdiction ${ }^{16}$. The ECHR has made clear declarations on limitations and exceptions to immunity in some judgments, especially on torture and jus cogens, the exceptions declared by the ECHR have also become the exceptions set out in Draft Article $7^{17}$, which was first proposed by the Special Rapporteur in her fifth report. Finally, although the decisions of the International criminal tribunals are in the context of international criminal jurisdiction, the Special Rapporteur still thought that some judgments are related to the purpose of the report, and took judgments of the International Military Tribunal at Nuremberg and the International Criminal Tribunal for the former Yugoslavia (ICTY) as practical factors to prove the formation of customary international law.

At the national legislative practice level, the rapporteur considered that there are only three national laws directly dealing with immunity of state officials. The others either only provide for immunity of state but not of state officials, or only applicable to civil litigation rather than criminal proceedings. Regarding the distinction between immunity ratione personae and immunity ratione materiae, the rapporteur cited the domestic laws of Belgium, the Netherlands, and the Republic of Niger to justify the possibility of exceptions to immunity. The rapporteur viewed the incorporation of Rome Statute as implementing laws, In view of the facts that Ireland, Mauritius, South Africa recognized in general no immunity can be invoked, and Canada, France, Germany cooperated with international tribunals to exclude the general immunity ${ }^{18}$. In short, the Special Rapporteur be-

${ }^{16}$ Fifth report, A/CN.4/701, para. 86.

${ }^{17}$ See Al-Adsani v. United Kingdom, Application No.35763/97, Judgment of 21 November 2001, Report of Judgment and Decisions 2001-XI, paras. 61-63.

${ }^{18}$ Fifth report, A/CN.4/701, paras. 57-59. 
lieved that national legislation has already covered immunity exceptions from both substantive and procedural dimensions.

With regard to national judicial practice, the Special Rapporteur conducts research and analysis by analyzing the rulings whether the immunity is applied declared by the national courts. Specifically, the Special Rapporteur recognized that the judgments adopted by various countries are not uniform in terms of immunity of state officials from criminal jurisdiction of state officials, even if the decision that immunity did not apply were based on different reasons. However, she insisted that domestic courts tend to imply limitations and exceptions to immunity in cases like international crimes, corruption crimes, and terrorism. Then she further concluded that, in general, the attitude of most countries towards immunity ratione materiae is accepting the application of limitations and exceptions to such immunity ${ }^{19}$.

In conclusion, although both the Special Rapporteur and the final work product of Draft Article 7 and its Commentary avoid the conclusion that the six exceptions to official immunity have been established as customary international law, they all strongly hint at such a conclusion or at least a trend in that direction (Shen, 2018). As a result, the Draft Article 7 was adopted by the ILC.

\section{Exceptions to Immunity Ratione Materiae Has Not Yet Constitute Customary International Law}

In the Nicaragua case, the ICJ confirmed that the formation of customary international law requires two factors: practice and opinio juris. The core of practice is that the judicial practice of various countries needs to meet the requirements of continuity, consistency, coherence and generality ${ }^{20}$. Viewing practices from the level of international law and domestic law, it could be found that the rule of immunity of state officials from foreign criminal jurisdiction is customary international law. The principle of sovereign equality and no jurisdiction among equals require that the sovereignty of one country cannot override the other, which ruled out the possibility of jurisdiction between countries (Wang, 2010). However, with regard to the exception of immunity of state officials from foreign criminal jurisdiction, the practice is not uniform and not enough to form a norm of customary international law.

\subsection{International Treaties and Judicial Practice}

\subsubsection{International Treaty Practice}

The 1961 Vienna Convention on Diplomatic Relations, the 1963 Vienna Convention on Consular Relations, and the 1969 United Nations Convention on Special Missions, which directly regulate the immunities of state officials, respectively deal with the privileges and immunities of diplomatic representatives, consular officials, and members of special missions. Article 31 of the Vienna ${ }^{19}$ Fifth report, A/CN.4/701, para. 121.

${ }^{20}$ Military and Paramilitary Activities in and against Nicaragua (Nicaragua v. United States of America), Judgment, I.C.J. Reports, 1986, para. 183. 
Convention on Diplomatic Relations and Article 31 of the United Nations Convention on Special Missions recognized that persons enjoying absolute immunity during their tenure are not subject to criminal jurisdiction. The Vienna Convention on Consular Relations stipulates that consular officials or other librarians do not enjoy absolute immunity, and the immunity the could enjoy are limited to acts performed in official status. The above-mentioned treaties provide only for immunity, none of them mention the limitations and exceptions to the immunity of state officials.

In addition to the aforementioned treaties that directly mention immunity, there are also some conventions that provide for personal criminal liability related to exceptions to immunity. The 1948 Convention on the Prevention and Punishment of the Crime of Genocide stipulates the individual criminal responsibility for the crime of genocide, and Article 6 stipulates the prosecution of persons who have committed the crime of genocide. Regarding the definition of person, Article 4 of the Convention lists the identity of the subject, whether it is a ruler, a public servant or a private person responsible for the constitution, they shall be punished, which implies that official status may also be responsible for the crime of genocide and may be sued. Furthermore, the four Geneva Conventions of 1949 all provide for effective criminal sanctions for those who seriously violate the conventions, commit inhumane acts, or commit international crimes. For the abovementioned criminals, each state party to the Convention is obliged to arrest and transfer such persons to the courts of that country regardless of nationality.

The above mentioned conventions on individual criminal responsibility do not explicitly exclude the application of immunity rules for state officials by the courts of the contracting states, nor do their preparatory work or other documents indicate that the contracting parties intend to exclude such immunity during the negotiation of these conventions. In essence, it only stipulated universal jurisdiction, and prescribed that each state party is obliged to hold criminal responsibility for any person who commits international crimes, including the official of the state who commits the crime. However, jurisdiction and immunity are two elements, the existence of jurisdiction is the starting point for the establishment of immunity, while the existence of universal jurisdiction does not detract from the importance of immunity as a means to protect the principle of national sovereignty and equality. On the contrary, the purpose of immunity is to prevent the exercise of jurisdiction.

\subsubsection{International Judicial Practice}

In the Arrest Warrant Case, the ICJ stated that the Minister of Foreign Affairs of the Democratic Republic of the Congo enjoys full immunity from criminal jurisdiction abroad during his entire term of office ${ }^{21}$. In its judgment, the ICJ noted that exceptions to immunity could not be inferred from the practice of States, even if the relevant acts constitute war crimes or crimes against humani-

${ }^{21}$ Arrest Warrant of 11 April 2000 (Democratic Republic of the Congo v. Belgium), Judgment, I.C.J. Reports, 2002, para. 54. 
ty $^{22}$. In Certain Questions of Mutual Assistance in Criminal Matters, the ICJ reiterated its statements and conclusions on the limitations and exceptions to immunity in the Arrest Warrant Case.

Different from the ICJ, although the ECHR considered that the right to litigation can be restricted, it must meet the three requirements that the law so stipulates, that the interests protected are proportionate to the limits of rights, and that the right to action is not absolutely $\operatorname{los}^{23}$. Although the ECHR has announced possible exceptions to immunity, it only defines the compatible relationship between civil jurisdiction immunity and litigation rights, and did not mention the immunity of state officials or criminal jurisdiction. The only related case is Jones et al. v. United Kingdom, which declared that the conclusions reached on the limitations and exceptions to state immunity can be applied to the civil jurisdiction immunity of state officials ${ }^{24}$. The ECHR went further on the issue of immunity exceptions, it still did not mention the limitations and exceptions to officials' criminal jurisdiction immunity.

The ICTY extended the immunity of state officials from criminal jurisdiction, arguing that there are exceptions to the immunity of officials in various international criminal courts or tribunals. In the Blaskić case, the court stated that according to the norms arising from the prohibition of war crimes, crimes against humanity, and genocide, the persons responsible for such crimes cannot share immunity even when acting in an official capacity ${ }^{25}$. The ICTY held the same position in other cases, but it should be noted that the court did not extend this position to cases brought in national courts, instead it limit the exceptions to immunity in court's own jurisdiction in accordance with the Nuremberg Charter.

Regarding the decisions of the international criminal tribunals cited by the Special Rapporteur, although some of the rulings explicitly deny the possibility of state officials invoking immunity from criminal jurisdiction, they are mainly based on the Nuremberg Charter and the Rome Statute, therefore, exceptions are only applicable to the party states rather than non-party states. In addition, the judgments of the international criminal tribunals can only be used as precedents for immunity from international criminal jurisdiction, but cannot be used as precedents to constitute a general practice of customary international law for immunity from national criminal jurisdiction alone.

\subsection{National Legislation and Judicial Practice}

\subsubsection{National Legislative Practice}

National legislation includes domestic laws that explicitly involve immunity and

\footnotetext{
${ }^{22}$ Arrest Warrant of 11 April 2000 (Democratic Republic of the Congo v. Belgium), Judgment, I.C.J. Reports, 2002, para. 58.

${ }^{23}$ Al-Adsani v.United Kingdom, Application No.35763/97, Judgment of 21 November 2001, Report of Judgment and Decisions 2001-XI, para.53; Jones and others v. United Kingdom, Application No.34356/06, Judgment of 02 June 2014, Report of Judgment and Decisions 2001-XI, para. 186.

${ }^{24}$ Jones and others v. United Kingdom, Application No.34356/06, Judgment of 02 June 2014, Report of Judgment and Decisions 2001-XI, paras. 204-206.

${ }^{25}$ Prosecutor v. Tihomir Blaskic, IT-95-14-AR 108, 29 October 1997, para. 41.
} 
other laws that regulate the state's reference to immunity in the jurisdiction of international crimes. In terms of domestic laws expressly involving immunity, most of them only provide for state immunity, only a tiny number of domestic laws mention the immunity of state officials. Even if the immunity of state officials is provided, most of them focus on the immunity ratione personae, some laws stipulates that the rule of immunity of state officials does not apply to criminal proceedings. Therefore, there are very few provisions on exceptions to the immunity of state officials from criminal jurisdiction, only three laws are related to the immunity exceptions researched in this article, the United States Foreign Sovereign Immunities Act (FSIA), the Canadian State Immunity Act (CSIA) and the Spanish Organic Act 16/2015.

Among the three above-mentioned domestic legislation, FSIA provides for exceptions to terrorism under the jurisdiction of foreign jurisdictions, while such provisions shall apply to need to meet the prerequisites that the foreign secretary appointed sponsor terrorism country. This makes the exception immunity only applicable to the acts performed by officials of a country that supports terrorism officially designated by the Secretary of State, reflecting very strong political intervention, making this clause difficult to have universal applicability. Similar to the United States, Canada added a support of terrorism exception when amending the State Immunity Act in 2012. As FSIA's excessive political involvement, CSIA is not universal due to excessive political involvement. Spanish Organic Act 16/2015 stipulates that state officials shall not enjoy immunity for acts of genocide, enforced disappearance, war crimes, and crimes against humanity committed during their term of office. Unlike the FSIA and CSIA, Spanish Organic Act 16/2015 stipulates a general exception to the immunity of state officials.

Among the domestic laws regulating international crimes, the Repression of Serious Violations of International Humanitarian Law Act of Belgium defines the immunity of state officials in Article 13 and provides for exceptions to immunity. Although the immunity ratione personae is absolute, the immunity ratione materiae have some exceptions. The International Crimes Act of Netherlands adopted similar provisions, it recognized the immunity of the foreign Heads of the State, but after the end of the service, the immunity will only apply to acts committed by the Head of State in an official capacity, and the information provided by the Netherlands government to the committee shows that international crimes will not be covered.

Even with the existence of the above-mentioned domestic legislation, it is still impossible to ignore the fact that only a few domestic laws deal with the exception issue. Most countries do not have clear regulations on immunity from jurisdiction of the state and state officials, instead, the response to immunity is the responsibility of the courts. Among the several domestic laws that are said to involve immunity of state officials, their focuses are on state immunity, which is not very relevant to the issue of state officials' immunity under customary international law. Belgium's 2003 Act and the Netherlands' 2003 Act only stipulate 
that no immunity shall be granted as recognized by international law, but have no reference to the current Draft Article 7.

\subsubsection{National Judicial Practice}

Although some national courts believe that there are limitations and exceptions to the immunity ratione materiae, the reasons for non-applicability of immunity are not consistent. Even the judgments made by the domestic courts of the same country sometimes held conflicting positions, and there are many differences in the handling of immunity in the face of the same facts. Some courts held that international crimes cannot be regarded as acts committed in an official capacity based on the gravity of the behavior of state officials, and some courts held that coercive law outweighed the immunity rule.

Take the Pinochet case (No. 3) as an example, the House of Lords in the trial of this case ruled that immunity ratione materiae was not applicable based on the Convention against Torture. The House of Lords considered that the nonapplicability of immunity was only applicable after the Convention entry into force in Britain,the defendant can still claim immunity for acts of torture committed by the defendant before December $8,1998^{26}$. This case can only be interpreted as non-immunity of acts within the scope of the current treaty for waiving immunity. It can be seen that the final decision in this case to not apply immunity is not based on customary international law, but based on international treaties. Therefore, this case cannot be used as an evidence for national judicial precedent to become practice of customary international law.

From the perspective of proving that immunity ratione materiae has developed into customary international law, the nine national judicial practice mentioned in the fifth report cannot fully prove the universality and continuity of this exception, and most of the cases actually do not support the exception. In Lozano v. Italy, state officials were eventually granted immunity ratione mate-

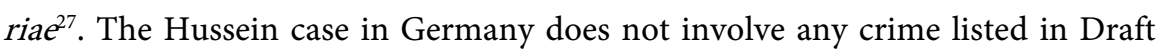
Article 7, and in terms of the assumption that the then President Hussein was no longer in office, the judgment did not indicate that immunity ratione materiae was not or shall not be recognized in such circumstances ${ }^{28}$. The other cases listed mainly involve failure to invoke immunity or waiver of immunity, and did not provide sufficient support for the non-immunity for state officials from foreign criminal jurisdiction under customary international law, which were not sufficient to constitute a general practice of immunity exceptions.

In summary, although there is no coherent evidence against the non-applicability of immunity, there is also not enough evidence to support that exceptions to immunity have become customary international law. The limited number of in-

\footnotetext{
${ }^{26}$ See Regina v. Bow Street Metropolitan Stipendiary Magistrate, (No. 3), House of Lords, United Kingdom, 24 March 1999, [2000] 1 A.C. 147.

${ }^{27}$ See Lozano v. Italy, Italy, Court of Cassation, Judgment of 24 July 2008, Oxford Reports on International Law in Domestic Courts, 1085 (IT 2008).

${ }^{28}$ See In re Hussein, Germany, Regional Superior Court of Cologne, Judgment of 16 May 2000. 2 Zs $1330 / 99$.
} 
ternational treaties and judicial practice, national legislation and judicial practice are neither sufficiently representative nor consistent, and it is not yet possible to prove that exceptions to immunity have formed customary international law. The ILC should consider the possibility of submitting proposals in accordance with the proposed law. At the same time, it should also conduct a review based on a careful and thorough analysis of the current law, only on this basis can the balance of interests between the principle of immunity and the punishment of impunity be achieved.

\section{Reasons for the Non-Applicability of the Immunity Exception}

Regarding the substance of the exception clause on immunity of state officials from foreign criminal jurisdiction, the countries participating in the discussion generally mentioned the need to strike a balance between preserving immunity to protect the sovereign equality and safeguarding the impunity of the most serious crimes under international law. Committing international crimes is the core issue of the debate on the limitations and exceptions to immunity of state officials from foreign criminal jurisdiction, owing to two elements: the relationship between international crimes and jus cogens, and the relationship between immunity and the fight against impunity. For the rules that have been determined as jus cogens, can the immunity exception be derived on the ground of the higher degree of effect of compulsory law? Regarding the trend of the international community's fight against impunity, is not applying the immunity exception a way of going against the international trend of development?

\subsection{The Exception to Immunity Ratione Materiae Should Still Apply to International Crimes}

Commitment of international crimes is the main defense for non-applicability of immunity, arguing that the conduct of a state official in an official capacity is the responsibility of the state, and does not apply to international crimes (Gao, 2007). The concept of international crime had not yet been clearly defined, although the ILC adopted Draft Article 7, it has made substantial amendments to the draft articles proposed by the Special Rapporteur ${ }^{29}$. In the fifth report, the Special Rapporteur listed the crimes for which immunity is not applicable for the first time, which is different from Draft Article 7 provisionally adopted by the ILC. The Special Rapporteur did not mention the crime of apartheid when it was first proposed, rather, it mentioned two instances of infringement exceptions and corruption in the territories that were later deleted. It can be seen that even the special rapporteur and the ILC have considerable disputes and differences on the definition of international crimes. Although Draft Article 7 was approved by most members, those in favor also regretted about the list of international crimes. Some members considered other serious crimes such as aggression, human traf${ }^{29}$ See ILC Sixty-ninth session (second part) Provisional summary record of the 3378th meeting, A/CN/4/SR.3378. 
ficking, terrorism should be included in the first paragraph of Draft Article $7^{30}$.

Those who support international crimes as exceptions to immunity either believed that such crimes should not be regarded as official acts, or that such crimes are extremely serious in nature should be regarded as exceptions to immunity. However, if the illegal official acts performed by state officials can still be regarded as official acts and ultimately attributed to the state, why do international crimes lose their official characteristics and no longer be attributed to the state? Why the foreign official has committed an international crime, his official status cannot be a reason for exemption or mitigation of his liability, and the customary international law rule of foreign official immunity is no longer applicable (Liao, 2013)? In addition, how to distinguish a crime from an ordinary crime and the most serious crime in the international community?

First, the application of immunity should be determined by the inherent rules of immunity, not from the perspective of international crimes. The theoretical basis for determining the nature of an official's behavior is the statement of the functional representative, and the fact is based on whether he performs official duties on behalf of the country. The immunity of state officials is not necessarily related to the illegality of the act, and the gravity of the crime should not affect the official nature of the act (Li, 2012). In addition, genocide and aggression are all related to national mechanisms and national policies, individuals cannot commit the above-mentioned international crimes on their own. Judge Wyngaert pointed out in his independent opinion on the Arrest Warrant Case that some crimes under international law can actually only be implemented as part of national policies through national means and mechanisms $s^{31}$. This claim has been reflected in judicial and academic studies, critics also admit this fact. Therefore, these so-called international crimes are still essentially acts of state officials performing official duties on behalf of the country. Even assuming that the most serious crime is no longer regarded as an act performed in an official capacity, at this time the act has lost its official nature and lost the theoretical basis for the state official's immunity ratione materiae. How can there be immunity ratione materiae from foreign criminal jurisdiction, and how can there be exceptions to immunity?

\subsection{The Exception to Immunity Ratione Materiae Is Not in Conflict with Jus Cogens}

Whether it does not regard international crimes as acts committed by state officials in their official capacity, or considers that international crimes themselves constitute exceptions to immunity, they all viewed international crimes as violations of the basic values and principles of the international community, arguing that such crimes violate jus cogens, and further considering that jus cogens were higher-level rules. The most relevant case to this issue is the Pinochet case in the United Kingdom, which emphasized that immunity shall not apply to interna-

${ }^{30}$ Provisional summary record of the 3378th meeting, pp. 13-16.

${ }^{31}$ Arrest Warrant of 11 April 2000 (Democratic Republic of the Congo v. Belgium), para. 36. 
tional crimes of a jus cogens nature ${ }^{32}$. The Italian Supreme Court, in the Ferrini case, stated that the commission of international crimes is a serious violation of fundamental human rights and universal values of the international community. These values are protected by international coercive norms, which take precedence over the principle of immunity, therefore, national courts had universal jurisdiction over crimes $^{33}$. When the immunity rules conflict with higher-level jus cogens rules, the procedural guarantee of state immunity should be automatically lifted without legal effect. Although the view of jus cogens is supported by some domestic courts, it has been rejected by the courts of other countries ${ }^{34}$.

It is undeniable that international crimes violate the values of the international community, genocide, crimes against humanity, and war crimes are all explicitly prohibited by jus cogens recognized by all parties. But is there really a conflict between jus cogens rules and immunity rules? In the State Jurisdiction Immunity Case, the ICJ held that state immunity and jus cogens dealt with different issues and operated at two levels without direct conflict between the two ${ }^{35}$. The state immunity rule is limited to determining whether the courts of one country can exercise jurisdiction over another country, it has nothing to do with whether the act of prosecution is lawful or illegal. Recognizing foreign state immunity under customary international law is not equivalent to confirming the lawfulness of the situation caused by the violation of the jus cogens. International customs have not yet formed a universal recognition that violations of jus cogens will lead to the non-applicability of national immunity (Li \& Xie, 2013). Similarly, the coercive features of jus cogens and national officials' immunity from criminal jurisdiction are not incompatible.

Secondly, there is no clear level of legal effect in international law, and there is no sufficient basis to prove that the effect of jus cogens is higher than that of immunity rules. Violation of jus cogens does not necessarily lead to the non-application of immunity. In the State Jurisdiction Immunity Case, the ICJ held that jus cogens rules cannot be derogated from, but the rules that determine the scope and extent of jurisdiction will not harm the substantive rules that have the status of jus cogens, and the concept of jus cogens did not require modification or substitution of the application of the immunity rule ${ }^{36}$. The ICJ also emphasized that state immunity is a procedural matter, a rule different from jus cogens that stipulates international crimes, and that violation of jus cogens does not automatically lead to exceptions to immunity ${ }^{37}$. The distinction between procedures and substance is also a method recognized by domestic courts to resolve the relationship between jus cogens and immunity, which does not depend on

\footnotetext{
${ }^{32}$ Third report on peremptory norms of general international law (jus coges), A/CN.4/714, para. 125.

${ }^{33}$ Ferrini v. Federal republic of Germany, Court of Cassation, Judgment of 11 March 2004, International Law Reports, Vol. 128, p. 674.

${ }^{34}$ Immunity of State officials from foreign criminal jurisdiction, Memorandum by the Secretariat, A/CN.4/596, para. 194.

${ }^{35}$ Jurisdictional Immunities of the State, Judgment, I.C.J. Reports, 2012, para. 95.

${ }^{36}$ Jurisdictional Immunities of the State, para. 95.

${ }^{37}$ Jurisdictional Immunities of the State, para. 93.
} 
the nature of the violation (Xie, 2014).

Finally, as a procedural rule, the immunity rule is related to the principle of due process, and the unique value of this principle is in the same position as other values. The value of the principle of due process (immunity rule) and the value of substantive rules (jus cogens) are not in conflict with each other, both domestic and international laws insist that the realization of substantive justice cannot be done at the expense of due process. The Chinese government also insists that immunity is a procedural rule, and procedural justice cannot be sacrificed for the pursuit of substantive justice (Xu, 2014).

In view of the fact that the immunity rules and the norms that criminalize international crimes deal with different issues, respectively belonging to two different areas, procedural law and substantive law, and there is almost no conflict between the two. Immunity does not affect the relevant acts stipulated by the jus cogens law, the immunity rule neither abolishes the responsibility for such acts, nor does it completely exclude the foreign criminal jurisdiction over state officials, and there is no evidence to prove that there is a hierarchy between jus cogens law and immunity. Even though the Special Rapporteur on jus cogens law supports the provision of exceptions to immunity for crimes that violate jus cogens, he still believed that the basis of the fifth report on immunity is unconvincing ${ }^{38}$. Therefore, it is not sufficient to identify the exception to immunity on the grounds of jus cogens.

\subsection{No Exception to Immunity Ratione Materiae Do Not Mean Impunity}

The fact that the perpetrator acted in an official capacity does not affect his liability under international criminal law (Werle \& JeßBerger, 2017), immunity is a procedural rule rather than a substantive rule, the application of immunity does not imply the disappearance of criminal liability that may arise from wrongful acts. After World War II, the Nuremberg Trials and the Tokyo Trials first put forward the principle of imputation "not related to official positions". With the establishment of a series of international criminal tribunals, international criminal law has made significant progress in jurisdiction over combating serious international crimes, the fight against impunity in international law has become a trend nowadays (Deng, 2016).

Immunity is a neutral rule that does not in itself generate international crimes, let alone encourage impunity $(\mathrm{Xu}, 2016)$. There is no direct causal relationship between the rule of immunity and the emergence of impunity in the international community, nor is there any absolutely inevitable connection between the two concepts, nor is there any presumption that immunity will lead to impunity. As a procedural rule, the immunity of a state official from foreign criminal jurisdiction may indeed hinder the prosecution of the official's crimes by a country other than the official's country of nationality, but immunity does not mean

${ }^{38}$ ILC Sixty-ninth session (first part) Provisional summary record of the 3361st meeting, A/CN.4/ SR.3361, 14 June 2017. 
exempting the official from criminal responsibility, nor does it mean tolerance of international crimes. On the contrary, the ICJ has pointed out that despite the immunity, the courts of the state can still determine the criminal responsibility of individuals without relying on the exercise of jurisdiction. In the State Jurisdiction Immunity Case, the ICJ emphasized the procedural nature of immunity that will not affect the definition of state responsibility, but only affects the possibility of prosecuting such responsibility through foreign jurisdiction ${ }^{39}$. Although this case is not a case concerning immunity of state officials from criminal jurisdiction, the judgment of this case is of instructive significance for analyzing the relationship between immunity and liability.

Regarding immunity from foreign criminal jurisdiction and individual criminal responsibility of state officials, the ICJ emphasized in the Arrest Warrant Case that the two are different concepts, granting of jurisdictional immunity to the Minister of Foreign Affairs did not mean that the person would be able to commit the crime with impunity ${ }^{40}$. There are many factors that lead to impunity, the only influence of immunity is to prevent the determination of responsibility through legal channels, but not directly lead to impunity for officials' international crimes. In this regard, the ICJ cited four solutions: prosecution by a state official's home court, waiving immunity by the state official's home country, holding the case after the state official has left office, and prosecution by an international criminal court with jurisdiction. In these four situations, state officials may still enter criminal proceedings and ultimately bear personal criminal responsibility.

\subsection{Summary}

To sum up, the three reasons supporting the exceptions to immunity ratione materiae are not sufficient, so the exception to immunity ratione materiae cannot be applied yet. First, the definition of international crime is not clear, international crimes cannot be effectively distinguished from official acts, and the application of exception to immunity shall be determined through the immunity rule rather than from the perspective of international crime. Second, there is no evidence to prove that the effectiveness of jus cogens is higher than that of immunity rule, and the exception to immunity ratione materiae and jus cogens are procedural rules and substantive rules respectively, so there is no conflict between them. Finally, there was no direct causal relationship between the immunity rule and impunity, immunity of state officials from foreign criminal jurisdiction was a different concept from individual criminal responsibility, so immunity ratione materiae did not equate to impunity.

\section{Conclusion}

Dealing with exceptions to immunity must follow the values and principles affected by the immunity of state officials from foreign criminal jurisdiction, as

${ }^{39}$ Jurisdictional Immunities of the State, Judgment, I.C.J. Reports 2012, para. 58.

${ }^{40}$ Arrest Warrant of 11 April 2000 (Democratic Republic of the Congo v. Belgium), para. 60. 
well as the values of national sovereignty equality and stability in international relations. The immunity exception may be easily abused and reduced to a political tool, harming the sovereignty of a country through abusive prosecution against officials of other countries, and thereby affecting the stability of state-to-state relations. Although Draft Article 7 stipulating the exception to immunity ratione materiae was supported by the majority of members and was provisionally adopted, the position of the ILC does not represent the general position of the international community, not to mention the fact that there were still a number of dissenting views even within the ILC itself. Regardless of final draft on the exceptions to the immunity ratione materiae, the draft will eventually be submitted to the UN General Assembly, and the final opinions of the UN member states on Draft Article 7 are still unknown.

To sum up, the legislative and judicial practices of immunity of state officials from foreign criminal jurisdiction are very different in various countries, the limited number of inconsistent practices has not established a unified general practice, although it cannot be interpreted that exceptions to immunity do not exist at all, it is also difficult to conclude that the immunity exception has formed a norm of customary international law. In addition, the non-official nature of international crimes, the higher effectiveness of jus cogens, and the fact that they are not conducive to the fight against impunity are not convincing enough to support the exception to immunity for state officials from foreign criminal jurisdiction. In this context, Commissioner Huang's view might be agreed that if there is no consensus on Draft Article 7, the committee should put aside this issue for the time being and discuss it later ${ }^{41}$. There are exceptions to immunity, but it is premature to discuss the issue of immunity exceptions. The focus of this topic should on granting state officials immunity from foreign criminal jurisdiction, rather than clarifying the crimes under international law in respect of which immunity ratione materiae shall not apply.

\section{Conflicts of Interest}

The authors declare no conflicts of interest regarding the publication of this paper.

\section{References}

Alebeek, R. V. (2018). The International Crime Exception in the ILC Draft Articles on the Immunity of State Officials from Foreign Criminal Jurisdiction: Two Steps Back. American Journal of International Law Unbound, 112, 27-32. https://doi.org/10.1017/aju.2018.12

Deng, H. (2016). Commentary on the Last Development Relating to the Immunity of State Officials from Foreign Criminal Jurisdiction. Chinese Review of International Law, 4, 114-128.

Gao, N. (2007). New Development of Individual Immunity from Jurisdiction of Interna-

${ }^{41}$ ILC Sixty-ninth session (second part) Provisional summary record of the 3371st meeting, A/CN.4/ SR.3371, p. 10. 
tional Criminal Responsibility. Journal of Xi'an Politics Institute of PLA, 5, 77-81.

Huang, H. K. (2014). On Immunity of State Officials from Foreign Criminal Jurisdiction. Chinese Journal of International Law, 1, 1-11. https://doi.org/10.1093/chinesejil/jmu009

Li, B., \& Xie, W. W. (2013). Also Concerning the Conflicts of Jus Cogens and State Immunity. Science of Law (Journal of Northwest University of Political Science and Law), $6,178-183$.

Li, L. L. (2012). Statement by Mr. Li Linlin, Chinese Delegate at the Sixth Committee of the 67th Session of the UN General Assembly on Report of the International Law Commission on the Work of Its 64th Session.

https://www.fmprc.gov.cn/ce/ceun/eng/chinaandun/legalaffairs/sixthcommittee/t98812 3.htm

Liao, M. W. (2013). The Value of Research on the Tension between Sovereignty State and International Criminal Law: Comment on the Anthology State Sovereignty and International Criminal Law. China Yearbook of International Law, 521-549.

Rosca, D. (2019). The Exceptions to Immunity of State Officials from Foreign Criminal Jurisdiction between the Legal Desideratum and Reality of the International Community. Romanian Journal International Law, 21, 77-97.

Shen, Q. M. (2018). Methodological Flaws in the ILC's Study on Exceptions to Immunity Ratione Materiae of State Officials from Foreign Criminal Jurisdiction. American Journal of International Law Unbound, 112, 9-15. https://doi.org/10.1017/aju.2018.9

Shi, X. X. (2020). Functional Immunity of State Officials from Foreign Criminal Jurisdiction: An Analysis in Light of the Khashoggi Incident. Chinese Review of International Law, 2, 38-50.

Wang, X. M. (2010). The Immunity of State Officials from Foreign Criminal Jurisdiction. Journal of Xi'an Jiaotong University (Social Sciences), 4, 67-74.

Werle, G., \& JeßBerge, F. (2017). Principle of International Criminal Law (p. 428, Translated by Wang, S.Z.). Beijing: The Commercial Press.

Xie, H. X. (2014). State Immunity and Jus Cogens in International Law. Legal Forum, 6, 114-124.

Xu, H. (2014). Statement by Mr. Xu Hong, Chinese Delegate, Director-General of the Department of Treaty and Law of the Ministry of Foreign Affairs of China at the 69th Session of the UN General Assembly on Agenda Item 78 Report of the 66th Session of the International Law Commission.

http://chnun.chinamission.org.cn/eng/chinaandun/legalaffairs/sixthcommittee1/t12070 44.htm

Zhu, L. J. (2019). The New Development of Immunity of State Officials from Foreign Criminal Jurisdiction: A Comment on the Jordan Appeals Decision in the ICC Bashir Case. Journal of International Law, 1, 133-147+169. 